\title{
Forum
}

\section{Another inconvenient truth: the failure of enforcement systems to save charismatic species}

\author{
ELIZA B ETH L. BENNETT
}

\begin{abstract}
In spite of significant recent advances in understanding how to conserve species we are failing to conserve some of the most beloved and charismatic, with severe population losses, shrinking ranges and extinctions of subspecies. The primary reason is hunting for illegal trade of highly valuable body parts, increasingly operated by sophisticated organized criminal syndicates supplying wealthy East Asian markets. Current enforcement systems were not established to tackle such crime, and weak governance, low capacity and inadequate resources facilitate the trade. To save these species this trade must be treated as serious crime, with allocation of sufficient resources, highly trained personnel, and appropriate technologies to allow it to be tackled effectively. Success in tackling this trade will necessitate commitment from governments and non-governmental organizations and the support of civil society.
\end{abstract}

Keywords Charismatic, enforcement, illegal trade, species

In testing $\mathrm{n}$ the first decade of the 21st century we have learned much about how to conserve species more effectively. We have become more skillful in strategic planning (IUCN/ SSC, 2008) and in applying this to range-wide priority setting and species-focused action planning (Sanderson et al., 2006; Oates et al., 2007). We are becoming more sophisticated in understanding how to identify and engage appropriate stakeholders in developing and implementing conservation programmes (Bodmer \& Puertas, 2000; Robinson \& Redford, 2004; Hill, 2009), in balancing the needs of conservation with those of local communities (Robinson, 2007; Nasi et al., 2008; Robinson \& Queiroz, in press) and in developing incentives to conserve species (Hutton \& Leader-Williams, 2003).

We are failing, however, to conserve some of the most charismatic and beloved species. The Sumatran rhinoceros Dicerorhinus sumatrensis is almost certainly now extinct in Thailand and probably in Peninsular Malaysia (Milliken et al., 2009b). In spite of increases in both black Diceros bicornis and white rhinoceroses Ceratotherium simum overall, two subspecies of African rhino have almost certainly gone extinct in the past decade as a result of illegal hunting:

Elizabeth L. Bennett Wildlife Conservation Society, 2300 Southern Blvd. Bronx, New York 10460, USA. Email ebennett@wcs.org

Received 26 July 2010. Revision requested 7 October 2010.

Accepted 9 December 2010. First published online 7 June 2011. the western black rhinoceros D. bicornis longipes and, in the past 3 years, the northern white rhinoceros C. simum cottoni (Milliken et al., 2009b). Even formerly seemingly-secure populations are now at risk: South Africa lost almost 230 rhinoceroses to poaching during January-October 2010, one every 30 hours (TRAFFIC, 2010a). The saiga antelope Saiga tatarica has suffered a catastrophic decline, with a loss of $>95 \%$ of its total population in the 15 years prior to 2005 (Milner-Gulland et al., 2001; Li et al., 2007). Less than 3,500 tigers Panthera tigris now occur in the wild, occupying less than $7 \%$ of their historical range (Sanderson et al., 2006) and, of these, $<1,000$ tigers are likely to be breeding females (Walston et al., 2010). With the tiger we are witnessing the tragic winking out of one of the planet's most beloved animals across its range, one population at a time, with recent extinctions in Nakai-Nam Theun in Lao PDR where tigers were seen frequently 15 years ago (A. Johnson, pers. comm.), and Sariska, Panna, and possibly Sanjay in India within the last 3 years (Ali, 2009).

The primary reason for all of these declines is hunting for illegal trade in highly valuable body parts. Such trade is increasingly controlled by organized criminal syndicates with sophisticated smuggling methods and modes of operation, frequently operating through countries with high levels of corruption (Zimmerman, 2003; Bennett, 2009; Milliken et al., 2009a; Christy, 2010; CITES Secretariat, 2010a). The trade is large-scale and commercialized: elaborate and costly hidden compartments in shipping containers or below wholesale shipments of sawn timber, fish or scrap products, in which are concealed massive quantities of wildlife products from ivory to bear paws and frozen pangolins (Anon, 2008a; Wasser et al., 2008; Guynup, 2010; Kramer, 2010). The traders are also light on their feet, frequently changing routes and modes of operation as enforcement commences in any one place, and continually working through the routes and means of least resistance (Davies, 2005; World Bank, 2005; Christy, 2010). The legislation and methods of addressing illegal wildlife trade in many countries were not developed to tackle this type of organized crime. Trade through e-commerce from web sites whose location is difficult to detect and who operate beyond the current realms of wildlife legislation and enforcement is a further challenge.

What is responsible for this increase in organized wildlife crime? The single greatest factor is the increasing demand for wildlife products from the wealthy countries of 
East Asia and the high prices these products command (TRAFFIC, 2008). Many of the criminal networks radiating out across Asia and Africa ultimately link to the markets of East Asia. Within Africa this often involves nationals from China, Thailand, Vietnam and other Asian countries operating within the continent (Milliken et al., 2009a,b). The trade is facilitated by weak governance and lack of capacity in many of the countries where the animals are hunted and in transit, compounded by the close link between government officials and big business, both legitimate (e.g. blue-fin tuna traders), illegitimate (e.g. pangolin traders), and the legally shady area between the two (e.g. tiger farms). Weak governance also extends beyond governments: ivory being transported by air from Africa to Asia in shipments greatly exceeding individual travel allowances shows that certain airlines are either lax or corrupt (CITES Secretariat, 2010b).

The scale of the trade is immense. Between January 2006 and September 2009 a minimum of 470 African rhinos were poached; snaring of rhinos for bushmeat has largely been replaced by targeted shooting, using assault weapons and high-powered rifles, to obtain the horns (Milliken et al., 2009b). Given its nature, obtaining exact trade figures for other species is largely impossible but data from seizures give some indication of the level of operations: the 24 tonnes of pangolins seized by Vietnamese authorities in March 2008 (Anon, 2008b) in two linked shipments from Indonesia destined for China; the 332 tiger bones and two tiger skulls, 531 saiga horns and 283 Asiatic black bear paws seized by the Russian authorities in 2007 near the border with China (Anon, 2007); the 239 African elephant tusks weighing an estimated $2 \mathrm{t}$ seized at Bangkok international airport en route from Nairobi to Lao PDR in February 2010 (TRAFFIC, 2010b); the $6.2 \mathrm{t}$ of ivory from Tanzania via Malaysia seized by the Vietnamese authorities in March 2009 (Anon, 2009a,b); and the total of $361.4 \mathrm{t}$ of ivory seized globally between 1989 and 2009 (Milliken et al., 2009a). The proportion of trade represented by these confiscations is unknown but it is likely to be the tip of the iceberg: of the 1,521 African rhino horns allegedly destined for East Asia between January 2006 and September 2009 only 43 were seized by authorities and a further 129 recovered in the field (Milliken et al., 2009b).

We have taken our eye off the ball. Enforcement is critical: old fashioned in concept but needing increasingly advanced methods to challenge the ever-more sophisticated methods of smuggling. Where enforcement is thorough, and with sufficient resources and personnel, it works, both at sites (Madhusudan \& Karanth, 2000; Milliken et al., 2009b) and along trade chains (CITES Secretariat, 2010c). Success stories involve long-term programmes based on good science and local knowledge, sufficient capacity supported by appropriate legal mechanisms to establish and enforce regulations, and monitoring programmes to facilitate adaptive management (Bennett, 2009). Successes also involve multiple partners in clear, multi-agency relationships to provide different skill sets and, critically, to provide accountability and transparency, leading to good management even in countries with high levels of corruption (Bennett, 2009).

But such programmes are lamentably rare and resources applied to combating such crime generally grossly inadequate. In most countries wildlife and protected area authorities are given low priority and thus are severely understaffed, undertrained, and underresourced. Wildlife laws are often anachronistic, dating from a time when this type of wildlife crime was rare or non-existent. More often than not systems are weak for protected area enforcement and even weaker for enforcement along trade chains and in markets, where the responsibility for enforcement is legally ambiguous and often lies with transportation or urban authorities whose interest and training in wildlife crime is negligible. The same lack of resources applies internationally. The ASEAN Wildlife Enforcement Network is often held up as a good example of an international initiative to combat wildlife crime (Christy, 2010) but its home base of Thailand remains one of the three countries most heavily implicated globally in the illicit trade in ivory (Milliken et al., 2009a). CITES and Interpol each only have a single person in charge of enforcement of wildlife crimes.

Tackling the issue by focusing on demand reduction is a challenge, given deeply ingrained cultural beliefs in the efficacy of certain wildlife medicines, leading to tacit support for the trade across many sectors of Asian society. Any change is likely to be on a generational timescale but we do not have that luxury of time for many of the species currently targeted by trade. In the short-term the only practical way to reduce demand is through enforcement, both acting as a deterrent and also demonstrating that this is not a socially acceptable norm. Meanwhile, in-depth research into what will cause widespread behaviour change is urgently needed.

To save some of the highly charismatic species before it is too late we have to start taking wildlife enforcement seriously. We must dedicate the intellectual, funding and personnel resources needed to supersede those of the criminal organizations involved. This requires greatly increased numbers of highly-trained and well-equipped staff at all points along the trade chain: most especially in core sites where the species are being hunted but also along key transportation routes and in end markets. It involves use of a wide array of technologies, whatever is most appropriate for the task in hand: sniffer dogs and X-ray machines for vehicles and shipping containers, user-friendly DNA testing kits and smartphone apps to aid in species identification, and state-of-the-art software to detect internet crime. Success necessitates a total change in the way that wildlife crime is treated by governments and wider society. Law enforcement agencies including customs and police must 
regard this as serious crime and its enforcement as part of their job. Encouragingly, in Asia the United Nations Office on Drugs and Crime has recently listed wildlife crime as one of their core foci and, in November 2010, the potentially powerful International Consortium on Combating Wildlife Crime (ICCWC) was signed into effect (Interpol, 2010).

To be effective in tackling wildlife crime national governments, drawing on the expertise of ICCWC members and others as needed, should start dedicating the scale of resources to illegal wildlife trade that they do to other serious crimes, including the provision of highly trained enforcement personnel. Members of the judiciaries in countries along the trade chain should be well informed, giving sentences appropriate to the value and scale of the crime. Critically important, enforcement agencies in developed countries should greatly step up their technical support to the less developed countries that are so often the sources of the traded wildlife, as well as curb demand at home, and multilateral, bilateral and private funding agencies should dedicate the level of resources needed to support such operations. Non-governmental organizations with in-depth, on-the-ground knowledge and technical skills can facilitate much of this through their local, national and international networks and knowledge bases. All of this requires the support of civil society and their appreciation of the full implications of illegal wildlife trade. Unless we start taking wildlife crime seriously and allocating the commitment and resources appropriate to tackling sophisticated, well-funded, globally-linked criminal operations, populations of some of the most beloved but economically prized charismatic species will continue to wink out across their range and, appallingly soon, altogether.

\section{Acknowledgements}

I am grateful for comments from John Robinson, Arlyne Johnson and two anonymous reviewers.

\section{References}

A LI, F.M. (2009) India Tiger Park 'Has No Tigers'. BBC News. Http:// news.bbc.co.uk/2/hi/south_asia/8150382.stm [accessed 20 March 2010].

Anon (2007) Huge Seizure of Tiger Skins, Bear Paws and Saiga Horns in Russian Far East. Http://www.wildlifeextra.com/go/news/russiatiger-skins.html\&template $=$ news_archive_item\#cr [accessed 20 March 2010].

Anon (2008a) Vietnam Seizes Thousands of Smuggled Pangolins. Http://www.earthtimes.org/articles/news/189494,vietnam-seizesthousands-of-smuggled-pangolins.html [accessed 20 March 2010].

Anon (2008b) Wild Animal Breeding Law Sparks Controversy. Http:// english.vietnamnet.vn/social/2008/06/787765/ [accessed 20 March 2010].

Anon (2009a) Tonnes of Elephant Tusks Smuggled into Vietnam. Agence France Press, 2 March.
ANON (2009b) Hai Phong Customs Investigates Ivory Smuggling. Http://english.vietnamnet.vn/social/2009/03/838942/ [accessed 20 March 2010].

Bennett, E.L. (2009) Social dimensions of managing hunting in tropical forests. In Wildlife and Society: The Science of Human Dimensions (eds M.J. Manfredo, J.J. Vaske, P.J. Brown, D.D. Decker \& E.A. Duke), pp. 289-300. Island Press, Washington, DC, USA.

Bodmer, R.E. \& Puertas, P.E. (2000) Community-based comanagement of wildlife in the Peruvian Amazon. In Hunting for Sustainability in Tropical Forests (eds J.G. Robinson \& E.L. Bennett), pp. 395-409. Columbia University Press, New York, USA.

Christy, B. (2010) Asia's Wildlife Trade: The Kingpin. National Geographic, January 2010. Http://ngm.nationalgeographic.com/ 2010/01/asian-wildlife/christy-text/1 [accessed 20 March 2010].

CITES SeCRETARIAT (2010a) Monitoring of Illegal Hunting in Elephant Range states. Report to the 15th Meeting of the Conference of the Parties, CoP 15 Doc. 44.2. Http://www.cites.org/eng/cop/15/doc/ E15-44-02.pdf [accessed 20 March 2010].

CITES SeCRetariat (2010b) Monitoring of Illegal Trade in Ivory and Other Elephant Specimens. Report to the 15th Meeting of the Conference of the Parties, CoP 15 Doc 44.1 (Rev. 1). Http:// www.cites.org/eng/cop/15/doc/E15-44-01.pdf [accessed 20 March 2010].

CiTES Secretariat (2010c) Rhinoceroses. Report to the 15th Meeting of the Conference of the Parties, CoP 15 Doc 45.1 (Rev. 1). Http:// www.cites.org/eng/cop/15/doc/E15-45-01.pdf [accessed 20 March 2010].

Davies, B. (2005) Black Market: Inside the Endangered Species Trade in Asia. Earth Aware Editions, San Rafael, USA.

Guynup, S. (2010) On the Ground: Pangolins in Peril. Defenders Magazine, Winter 2010. Washington, DC, USA. Http://www. defenders.org/newsroom/defenders_magazine/winter_2010/on the_ground_pangolins_in_peril.php [accessed 3 December 2010].

Hill, C.M. (2009) Working with communities to achieve conservation goals. In Wildlife and Society: The Science of Human Dimensions (eds M.J. Manfredo, J.J. Vaske, P.J. Brown, D.D. Decker \& E.A. Duke), pp. 117-128. Island Press, Washington, DC, USA.

Hutton, J.M. \& Leader-Williams, N. (2003). Sustainable use and incentive-driven conservation: realigning human and conservation interests. Oryx, 37, 215-226.

Interpol (2010) Powerful Alliance to Fight Wildlife Crime Comes into Effect. Http://www.interpol.int/Public/ICPO/PressReleases/ PR2010/PRo98.asp [accessed 3 December 2010].

IUCN/SSC (2008) Strategic Planning for Species Conservation: A Handbook. Version 1.o. IUCN Species Survival Commission, Gland, Switzerland.

Kramer, A. (2010) At Russia-China Border, Bear Paws Sell Best. New York Times, 30 June 2010. Http://www.nytimes.com/2010/o6/30/ world/asia/3oanimals.html [accessed 3 December 2010].

Li, L., Zhou, Y. \& BennetT, E.L. (2007) Report of a Survey on Saiga Horn in Markets in China. Report to the 14th Meeting of the CITES Conference of the Parties, CoP14 Inf 14. Http:// www.cites.org/common/cop/14/inf/E14i-14.pdf [accessed 20 March 2010].

Madhusudan, M.D. \& Karanth, K.U. (2000) Hunting for an answer: is local hunting compatible with large mammal conservation in India? In Hunting for Sustainability in Tropical Forests (eds J.G. Robinson \& E.L. Bennett), pp. 339-355. Columbia University Press, New York, USA.

Milliken, T., Emslie, R.H. \& Talukdar, B. (2009a) African and Asian Rhinoceroses-Status, Conservation and Trade. A report from the IUCN Species Survival Commission African and Asian 
Rhino Specialist Groups and TRAFFIC to the CITES Secretariat pursuant to Resolution Conf. 9.14 (Rev. CoP14) and Decision 14.89. Report to the 15th Meeting of the CITES Conference of the Parties, CoP 15 Doc. 45.1 (Rev1) (Annex). Http://www.cites.org/ eng/cop/15/doc/E15-45-01A.pdf [accessed 20 March 2010].

Milliken, T., Burn, R.W. \& Sangalakula, L. (2009b) The Elephant Trade Information System (ETIS) and the illicit trade in ivory. Report to the 15th Meeting of the CITES Conference of the Parties, CoP 15, Doc. 44.1 Annex. Http://www.cites.org/common/ cop/15/doc/E15-44-01A.pdf [accessed 20 March 2010].

Milner-Gulland, E.J., Kholodova, M.V., Bekenov, A., Bukreeva, O.M., Grachev, A., Amgalan, L. \& Lushcherina, A.A. (2001) Dramatic declines in saiga antelope population. Oryx, 35, 340-345.

Nasi, R., Brown, D., Wilkie, D., Bennett, E., Tutin, C., van Tol, G. \& Christophersen, T. (2008) Conservation and Use of Wildlife-Based Resources: The Bushmeat Crisis. Secretariat of the Convention on Biological Diversity, Montreal, and Center for International Forestry Research, Bogor, Indonesia. Technical Series no. 33 .

Oates, J.F., Sunderland-Groves, J., Bergl, R., Dunn, A., Nicholas, A., TaKang, E. et al. (2007). Regional Action Plan for the Conservation of the Cross River Gorilla (Gorilla gorilla diehli). IUCN/Species Survival Commission Primate Specialist Group and Conservation International, Arlington, USA.

Robinson, J.G. (2007) Recognizing differences and establishing clear-eyed partnerships: a response to Vermeulen and Sheil. Oryx, $41,443-444$.

Robinson, J.G. \& Queiroz, H. (2011) Márcio Ayres: new approaches to the conservation and management of protected areas in Amazonia. In The Amazon Várzea: The Decade Past and the Decade Ahead (eds M. Pinedo-Vasquez, M.L. Ruffino, R.R. Sears, E.S. Brondizio \& C. Padoch), Springer Verlag and New York Botanical Garden Press, New York, USA.

Robinson, J.G. \& REDFORD, K.H. (2004) Jack of all trades, master of none: inherent contradictions among ICD approaches. In Getting Biodiversity Projects to Work: Towards More Effective Conservation and Development (eds T.O. McShane \& M.P. Wells), pp. 1034. Columbia University Press, New York, USA.

Sanderson, E., Forrest, J., Loucks, C., Ginsberg, J. \& Dinerstein, E. (2006) Setting Priorities for the Conservation and
Recovery of Wild Tigers: 2005-2015: The Technical Assessment. Wildlife Conservation Society, WWF, Smithsonian, and National Fish \& Wildlife Foundation-Save the Tiger Fund, New York, and Washington, DC, USA.

TRAFFIC (2008) What's Driving the Wildlife Trade? A Review of Expert Opinion on Economic and Social Drivers of the Wildlife Trade and Trade Control Efforts in Cambodia, Indonesia, Lao $P D R$ and Vietnam. East Asia and Pacific Region Sustainable Development Department, World Bank, Washington, DC, USA.

TRAFFIC (2010a) South African Delegates Visit Viet Nam to Address Illegal Rhino Horn Trade. Http://www.traffic.org/home/2010/10/ 20/south-african-delegates-visit-viet-nam-to-address-illegalrh.html [accessed 3 December 2010].

TRAFFIC (2010b) Major Ivory Seizure in Thailand. Http:// www.traffic.org/home/2010/2/27/major-ivory-seizure-in-thailand.html [accessed 3 December 2010].

Walston, J., Robinson, J.G., Bennett, E.L., Breitenmoser, U., da Fonseca, G.A.B., Goodrich, J. et al. (2010). Bringing the tiger back from the brink - the six percent solution. PLoS Biology, 8(9), e1000485. DOI: 10.1371/journal.pbio.1000485.

Wasser, S.K., Clark, W.J., Drori, O., Kisamo, E.S., Mailand, C., Mutyoвa, B. \& Stephens, M. (2008). Combating the illegal trade in African elephant ivory with DNA forensics. Conservation Biology, 22, 1065-1071.

World BANK (2005) Going, Going, Gone... The Illegal Trade in Wildife in East and South-east Asia. Environment and Social Development Department, East Asia and Pacific Region, World Bank, Washington DC, USA.

Zimmerman, M.E. (2003) The black market for wildlife: combating transnational organized crime in the illegal wildlife trade. Vanderbilt Journal of Transnational Law, 36, 1657-1689.

\section{Biographical sketch}

Elizabeth Bennett is Vice President for Species Conservation at the Wildlife Conservation Society. Her research interests include management of hunting and wildlife trade, and strategic planning for wildlife conservation. 